\title{
On Being and Becoming the "Ideal" Muslim Women: Girlhood Narratives of Young "Indonesian Muslims in Pesantren
}

\author{
$1^{\text {st }}$ Sovia Nur Khalida \\ English Studies Program, Faculty of \\ Humanities, \\ Universitas Indonesia, \\ Depok, Indonesia \\ sovia.nur@ui.ac.id
}

\author{
$2^{\text {nd }}$ Herlin Putri Indah Destari* \\ Area Studies Department, Faculty of \\ Humanities, \\ Universitas Indonesia, \\ Depok, Indonesia \\ herlindestari@gmail.com
}

\begin{abstract}
This research aims to explore how female students of Pondok Pesantren Kebon Jambu Al Islamy, Cirebon, form their identity through their girlhood experiences. Their experiences are analyzed through construction narratives ranging from social and communal to personal narratives. Using the concepts of narrative identity from McAdams and McLean, this research suggests that girlhood narratives differ for each individual student, despite them being in the same educational institution. The research also found that their narratives of girlhood draw heavily from the many prevailing narratives they have encountered in life. In this process, mainly, the pious critical agency offered by the pesantren and actively promoted by its leader seems to play a crucial role in reconstructing their understanding of what being and becoming an "ideal" Muslim woman means.
\end{abstract}

Keywords-Girlhood studies, narrative identity, pious critical agency, pesantren.

\section{INTRODUCTION}

Pesantren refers to traditional Indonesian schools that focus on religious teachings. There are approximately more than 25,000 pesantrens in Indonesia, mainly spread throughout Java. Most of these schools are led by one influential clerk, who is generally male or is usually as renowned as the ulama. There are also a number of pesantrens led by female clerks. However, the appointment of female ulama is usually because of special conditions, not by default. This is a result of the region's predominantly male-dominated culture, as in Javanese feudalism and Islamic male-centric value renditions.

Pondok Pesantren Kebon Jambu Al Islamy, Cirebon (PPKJ), applies the madrasah method, which allows for both the teaching of Islamic verses and general education simultaneously. Just like any other pesantren in Indonesia, PPKJ also teaches classic Islamic literature and kitab kuning (The Yellow Book). What makes PPKJ different from other pesantrens in Indonesia is the fact that it actively promotes itself as a progressive pesantren in which they actively and openly support gender equality. Led by a female ulama, $\mathrm{Hj}$. Masriyah Amva, it offers a different understanding of gender equality from a religious approach.

A number of studies have examined various variables that contribute to the experiences of girlhood. However, most of these girlhood studies have focused more on urban adolescent girls in secular contexts, whereas very few of them have discussed the experiences of girls growing up in suburbanrural areas, particularly in faith-based settings. For example,
Hicks [1] argues that responsive pedagogy bridges students and teachers in generating and appreciating diversity in language and identity representation while not interfering with the girls' dreams. Meanwhile, Wardman [2], in her work about the representation of girlhood within all-girls elite schools' promotional brochures, argues that the depiction of wellrounded girls as the expected result of attending an all-girls elite school is still highly associated with romanticized femininity. Coulter [3] states that the political use of "fun" in girlhood has somehow become a fantasy of 21 st-century girlhood with its infamous girl power slogans being depoliticized and shrunk as potential economic subjects. Meanwhile, previous studies on pesantren culture have discussed the pedagogy [4] and kinship aspects of pesantren [5] and have rarely discussed the students' experiences growing up.

In recent years, there has been great interest in studies on both pesantren culture and girlhood experiences in various cultural backgrounds, but very few of them have spoken about identity construction and the intersection of these concepts. PPKJ seems to offer a different construct of how an "ideal" woman should be when compared to what has been constructed in the general perspective of girlhood in Cirebonese society. This research aims to contribute to the girlhood studies by exploring girlhood experiences in rural and faith-based institution settings, identity formation, and how prevailing narratives on girlhood from the girls' families and community may affect this process.

\section{METHOD}

This particular research used a case study approach that focused specifically on the experiences of adolescent girls in the bounded context of a school environment. The data were collected through observation notes, interviews, and reflective journals kept by the researcher. Because this research was intended to focus on the thoughts and feelings of individual respondents, semi-structured and non-structured interviews were conducted at an initial meeting and during the fieldwork with nine female students, four senior residents, and the pesantren leader in November 2018. In relation to the research question, responses that were mainly related to issues of girlhood, pious critical agency, and identity formation were noted for further analysis. 


\section{RESULT AND DISCUSSION}

\section{A. Social and Communal Narrative}

In gathering supportive details regarding how to describe the manner in which the people of Cirebon construct their ideas about girlhood, I interviewed a senior student named Nadia. She believes that there are many factors to consider before concluding one notion about girlhood narratives, including varying social classes, heterogeneity among the Cirebon people as a community, and personal opinions (Online interview, May 8, 2019). She points out that diversity in Cirebon contributes to different understandings of girlhood construction, including, for example, the urban-rural context as well as racial, religious, and educational backgrounds. She explained, for example, that academia and pesantren personalities have different ideas about how an ideal girl should be. In the general education scene, an ideal girl should be outspoken and ambitious while putting forth equality and mubadalah (reciprocity) in socializing with boys. Meanwhile, the general perception of a pesantren girl usually revolves around her capability to understand religious scriptures and to be docile and pious.

According to a study on linking empowerment with narrative, Rappaport [6] defines dominant cultural narratives, or short social narratives, as overlearned stories widely spread by mass media or social institutions that reach the lives of almost all people. In Cirebonese social narratives about girlhood, the experience of living as a girl is mainly focused on docility and piety. Even though there have been some new attempts of girl empowerment, being obedient and pious is still the most crucial aspect in defining "what makes an ideal girl" as a guideline in girlhood. However, as the people of Cirebon become more progressive, they begin to acknowledge the different experiences girls have when growing up. They begin to recognize differences, be it regarding social class, educational background, religion, race, or urban-rural differences. Taking on the PPKJ case, the pesantren and general Cirebonese construct of girlhood are intertwined and developed as a communal narrative.

In PPKJ, they have a different understanding of girlhood. $\mathrm{Hj}$. Masriyah Amva, who the students usually call Bu Nyai, attempts to offer a new understanding that being capable in general affairs, performing piety, and promoting equality are things every girl should master. In an interview with Bu Nyai in November 2018, she stated that Islam supports equality just by looking at the religious scriptures, in this case, the Quran and the Hadith. However, it is also essential to recognize that the conventional interpretation of Islamic values is still heavily saturated with ancient Arabian culture, which put women in a subordinate position below men.

Rather than just simply intertwining the general Cirebonese and common pesantren construct of girlhood, $\mathrm{Bu}$ Nyai puts her narrative and experiences into a new philosophy for her pupils. She emphasizes her religious rendezvous in finding what it means to be a Muslim woman as something pious and progressive in some way. By sharing her philosophy and resonating with her power as the leader and teacher the pupils look up to the most, she has ensured that such a pious rendition of gender equality has become part of the female students' construct of girlhood. It helps them find themselves and their life philosophy. It also establishes a new set of values to follow in narrating each female student's personal narrative of girlhood.

\section{B. Pious Critical Agency and Personal Identity Construction}

As explained above, the attempt by Bu Nyai to provide a new understanding of gender equality through a religious approach can be considered one attempt to perform pious critical agency (PCA). Following the definition, as stated by Rachel Rinaldo [7], PCA is an opportunity for people of beliefs to engage in and manifest critical perspectives in their reading of religious texts. Mahmood [8] also points out that the performance of this kind of agency challenges the presumably Western-centered feminist values while also conforming to religious ideals. In Islamic and feminism contexts, this may result in an intersection of both worlds in negotiating and compromising religious and progressivity needs.

Through the medium of classes in the pesantren, Bu Nyai has implanted values about female empowerment not only through formal classes in which students sit down with books and listen to lectures but also through a personal approach. Bu Nyai is known for having the habit of using a friendly and motherly approach with her students. For senior residents in particular, she not only talks about what is going on around the pesantren affairs but also listens to the girls' challenges in growing up as Muslim women. The age at which a student becomes a senior resident is an awkward age (around 18-20 years old), when they are too old to be considered a girl but too young to acquire the societal expectations of being a woman. The standard age of maturity in rural areas usually occurs earlier, as it does in Cirebon and its surrounding regions. Seeing this, Bu Nyai always attempts to ensure that these senior residents acknowledge what it takes to be a fully grown woman, which includes self-reliance and empowerment, as stated above. Nadia, the senior student I mentioned above, said that sometimes Bu Nyai calls her up randomly just to check up on her and some of her friends.

$\mathrm{Bu}$ Nyai always mentions the importance of being both pious and critical. Being pious is essential as they are in a religious, academic setting, where piety is the canon of life. On the other hand, she also always emphasizes how being progressive and outspoken is just as important. For example, in our interview in November 2018, she explained that women should be capable of making themselves self-sufficient both emotionally and financially. She argued that even though in Islam, some believe that it is a man's job to provide for his family, women still need to do the same. This applies not only to putting their skills to good use but also to fully functioning as human beings. It is not that she intends to encourage her students to take a more powerful position above their husbands, which could be considered sinful, but it is more about realizing that there is so much to do and achieve in life.

By examining how Bu Nyai always emphasizes the possible negotiation between piety and "worldly" needs, there emerges is an obvious example of agency attempt. Rinaldo [7] highlights that agency is usually understood as one's capability to make choices and to opt out of any. Despite the early Western feminist constructs in which piety and obedience resemble oppression, PCA offers an opportunity for women to practice piety as a matter of choice. Here, PCA focuses more on how women are included in the discussion of 
public matters to prove their presence and interest within religious affairs. PCA also allows women to interpret religious text to fit with what they think does justice for them; in other words, PCA allows women to avoid the perpetuation of patriarchal interpretation of religious texts in practices.

Meanwhile, from the students' side, the reaction toward all the narratives before them was that the social and communal narratives help them identify who they are. So far, among my respondents, there have only been those who negotiate and/or those who immediately comply with the communal narrative. There has not been a response that opposes Bu Nyai's teachings about girlhood and gender equality.

For example, Rahmi, a sophomore university student who is also a sophomore student in PPKJ, in our interview in October 2018, agreed with Bu Nyai's teaching in which she emphasizes being an independent woman. Based on her experience, Rahmi's mother is also working to provide for her family. She has no trouble perceiving different narratives about girlhood because both her social background and communal narrative have the same vision. The only trouble she admits facing is how people around her, mostly her Sundanese friends, sometimes think that she is too "masculine" for a girl. She sometimes feels sad about this because it is a result of her cultural background as a Palembangnese, who the Sundanese tend to view less softspoken than the Sundanese people. She is afraid that this kind of prejudice could affect her social life and acceptance as a girl within the community.

I conducted interviews with seven young girls with seven different stories. They were all senior year high school students and had been in PPKJ for six years. They all have different family backgrounds and expectations of what to do in the future. Shanaz (17) told me that she is expected to go to the State Polytechnic of Finance to pursue a junior diploma degree so that she can work right after her schooling and support the family's finances. She said this was also her choice because she wants to learn about taxation. Meanwhile, Hasna (17) said that her family let her choose whatever she wanted to study as long as she can easily get a job.

Based on this interview, I also got a new piece of information that students at PPKJ are equipped with sex education because PPKJ does not want the girls to commit to adulthood emptyhanded. Sex is considered too taboo to be discussed openly in public, but fortunately, Islam has a kitab kuning (The Yellow Book) that addresses sex education. In this sex education, the girls are taught that they should not only make their husbands happy but also put forward consent. Shanaz said, "Yes, we are taught about safe jima' (sexual intercourse) in Fathul Izar on our fifth year here, and about menstruation, postnatal bleeding, and many others in Uyunul Masa' $i l$ but this has been quite a long ago. This is part of Figh (instructions on religious practice)." As she mentions above, the book Fathul Izar teaches them the practices of having sex, including the do's and don'ts, having a healthy sex life, and how to clean up to prevent sexually transmitted diseases. Meanwhile, in the latter book, Uyunul Masa'il, they are taught about feminine hygiene. Growing in a traditional background, it is still not widely accepted to speak about female genitals and menstruation in the public sphere, even though they are inevitable and part of human physiology. In order to give the girls a scholarly explanation about feminine hygiene, the book is written to give them a safe space to discuss the topic only among themselves. The topics range from how to handle menstruation, to cleaning up after menstruation before women can get back into their praying routines, to how to handle postnatal bleeding before going back to their praying routines. The book Uyunul Masa'il is taught during the girls' second year at the pesantren, approximately when they reach the second year of middle school. It is the age at which they are going through puberty, which also includes menarche and their first exemption from doing the five-time prayer and other practices, such as fasting and reading the Quran.

When I asked them if they had any specific response while receiving all this information, they claimed that they were very uncomfortable at first. Sari (17) confessed that after the lecture, she saw her male friends differently and was somehow afraid of them regarding what they could do in bed. These girls agreed that they were scared the boys might objectify them after attending the same lecture. Hasna said that the lecture was very noisy because all the girls screamed from the explicit explanations, especially about female sexuality. They were terrified of what might happen during sexual intercourse.

Even though they might seem reluctant and unexposed to sexuality, the lectures on sexual harassment have made a difference for the female students of PPKJ. These seven girls said that they actively participated in workshops on sexual harassment conducted by the Mawar Balqis Women Crisis Center. PPKJ invited the crisis center to educate the girls about the danger of sexual harassment and how to deal with this when it happens to the people around them. The lectures were only attended by the female students. The response from attending the workshops, according to Shanaz and her friends, was that they felt they had become more aware and alert about such things. They also promised to take care of each other and not to give any prejudice if one of their friends becomes a victim of sexual harassment. In the discussion about abortion, they were terrified to think that it might be the best way to get away from rape cases. Shanaz said, "It is much easier for men. All (the burdens) is on the women, right? The one who gets punished, the one who has the baby. And I don't think that to marry the rapist or to do abortion is a good way to resolve rape cases. We need to call out on the rapist, too."

After hearing from different students regarding how they experience girlhood differently and how they talked more about the things that appeal to them the most, it is safe to say that differences in perceiving girlhood constructs and experiencing girlhood also help them construct their identities differently. Even though the pesantren has provided a set of separate understandings for the girls to look up to, they still have their personal views on the matter. Some of them admit that sometimes they cannot understand some parts of what Bu Nyai teaches them. For them, some of Bu Nyai's philosophy is difficult to fathom. Even so, these students are still entitled to the notion that the philosophy is significant in their lives as well as in their identities as PPKJ students.

Tracing back to McAdams and McLean's (2013) [9] explanation about narrative identity, it is stated that narrative identity builds slowly over time as the narrators tell stories about their experiences to the people around them. This goes along with the findings in PPKJ. The female students end up constructing their identities as pesantren students, Cirebonese pesantren students, and PPKJ students. Each of the social and 
communal narratives is interpreted differently by each of the girls because they also relate this to their own experiences and life values. Relating the personal narratives to the PCA taught by Bu Nyai, it has become a profound and distinctive way of defining the girls' identities and validating their girlhood experiences. The PCA offers a negotiation space for the girls to rethink and reassess the way they see Islam, girlhood, and the progressive values that are embedded in their lives. How their personal experiences are shared with their friends and how the reciprocity among them works also help to strengthen their narrative identity constructs. However, their narrative identities as PPKJ students are mainly temporal as they are going to graduate when they finish their education there.

McAdams and McLean [9] further highlight that when someone important in other person's life agrees upon or validates their interpretation of their personal story, the narrator will likely tend to stick to that narrative and incorporate the value in shaping their identity. In this matter, $\mathrm{Bu}$ Nyai's validation in defining how the girls should be is vital in constructing their identities. The female students of this pesantren see Bu Nyai not only as a teacher but also as their role model in becoming women in the future. Validation from others, including their fellow students, also shapes how they see their own identity. For example, when someone shares something quite personal and her friends affirm it, active and attentive listening also helps build validation; thus, the response this person gets can be incorporated into her life philosophy and identity.

\section{CONCLUSION}

In this study, the intersection among progressivity, rural and social constructs, religion, and feudalistic power relations has created a distinctive narrative of girlhood. The girlhood narrative from Pondok Pesantren Kebon Jambu, Cirebon, is quite unique because it also involves PCA. The existence of PCA in this matter is important as it shapes a new understanding of Islamic renditions of gender equality. The notion that is always emphasized by the principal religious leader, Hj. Masriyah Amva, also known as Bu Nyai, in PPKJ has become an essential foundation in shaping the girls' perspective in reevaluating their experiences growing up as girls. These experiences were analyzed through the construction of narratives ranging from social and communal to personal narratives. In the end, all the elements mentioned above have constructed the girls' identities, which has helped them position themselves in society. In general, the communal narrative constructs of the female students of Pondok Pesantren Kebon Jambu Al Islamy, Cirebon, are young female Muslim scholars who uphold both piety and progressivity to go beyond the stereotypes of female pesantren students. The communal narrative allows the girls to have different choices in pursuing their dreams as long as they include piety to Allah, a long-running education, and purposefulness in the surrounding community.

\section{NOTES}

All names above except for K.H. Muhammad and $\mathrm{Hj}$. Masriyah Amva are pseudonyms.

\section{Closing}

Utmost gratitude and respect for $\mathrm{Hj}$. Masriyah Amva and her students in Pondok Pesantren Kebon Jambu Al Islamy, Cirebon, and FIB UI community service program for introducing us into this exceptional pesantren.

\section{REFERENCES}

[1] Hicks, D. (2005). Cultural Hauntings: Girlhood Fictions from Working-Poor America. Qualitative Inquiry, Vol 11 (2), pp. 170-190. Retrieved from https://journals.sagepub.com/doi/pdf/10.1177/1077800403261859, April 13, 2019.

[2] Wardman, N., (2010). Starry eyes and subservient selves: Portraits of 'well-rounded' girlhood in prospectuses of all-girls elite private schools. Australian Journal of Education, Vol 54 (3), pp. 249-261. Retrieved from https://journals.sagepub.com/doi/pdf/10.1177/000494411005400303, April 13, 2019

[3] Coulter, N. (2018). “Frappes, Friends, and Fun”: Affective Labor and Cultural Industry of Girlhood. Journal of Consumer Culture, Vol 0 (0), pp. $1-14$ Retrieved from https://journals.sagepub.com/doi/pdf/10.1177/1469540518806954, April 13, 2019.

[4] Pohl, F. (2006). Islamic Education and Civil Society: Reflection on PesantrenTradition in Contemporary Indonesia. The University of Chicago Press on behalf of the Comparative and International Education Society: Comparative Education Review, Vol. 50, No. 3, Special Issue on Islam andEducation-Myths and Truths, pp. 389-409. Retrieved from http://www.jstor.org/stable/10.1086/503662, September 25, 2018.

[5] Turmudi, E. (2006). Struggling of The Umma: Changing Leadership Roles in Jombang, East Java. ChapterKiai and the Pesantren. (n.d.): ANU Press. Retrieved from http://www.jstor.org/stable/j.ctt2jbk2d.9, September 25, 2018.

[6] Rappaport, J. (1995). Empowerment Meets Narrative: Listening to Stories and Creating Settings. American Journal of Community Psychology, Vol. 23, No. 5, pp. 795-807. Retrieved from https://link.springer.com/article/10.1007/BF02506992, April 15, 2019.

[7] Rinaldo, R. (2014). Pious and Critical: Muslim Women Activists and the Questions of Agency. Gender and Society, Vol 28 (6), pp. 824-846. Retrieved from https://journals.sagepub.com/doi/pdf/10.1177/0891243214549352, May 2, 2019.

[8] Mahmood, S. (2005). The Politics of Piety: The Islamic Revival and The Feminist Subject. Princeton, New Jersey: Princeton University Press.

[9] McAdams, D. \& McLean, K. (2013). Narrative Identity. Current Directions in Psychological Science, 22 (3), pp. 233-238. Retrieved from https://doi.org/10.1177/0963721413475622, April 20, 2019.

[10] Padawer, A. (2018). Girls' Work in Rural Intercultural Setting: Formative Experiences and Identity in Peasant Childhood. Girlhood Studies, Vol. 11, No. 2, pp. 95-110. Retrieved from http://scihub.tw/10.3167/ghs.2018.110208, May 11, 2019 